\title{
Pharmacological Treatment of Bipolar Depression: What are the Current and Emerging Options?
}

This article was published in the following Dove Press journal:

Neuropsychiatric Disease and Treatment

\section{Nefize Yalin \\ Allan $\mathrm{H}$ Young (D)}

Centre for Affective Disorders, Department of Psychological Medicine, Institute of Psychiatry, Psychology and Neuroscience, London, UK
Correspondence: Allan H Young Centre for Affective Disorders, Department of Psychological Medicine, Institute of Psychiatry, Psychology and Neuroscience, King's College, London, UK $\mathrm{Tel}+02078485895$

Fax +02078480298 ,

Email allan.young@kcl.ac.uk
Abstract: Depression accounts for the predominant burden associated with bipolar disorder. The identification and management of bipolar depression are challenging, since bipolar depression differs from unipolar depression, responding poorly to traditional antidepressants, which may also induce a switch to hypomania/mania, mixed states and/or cause rapid cycling. Current treatment options for bipolar depression are limited and guidelines vary greatly in their recommendations, reflecting gaps and inconsistencies in the current evidence base. Moreover, some treatment options, such as quetiapine and olanzapine-fluoxetine, although clearly efficacious, may be associated with adverse cardiometabolic side effects, which can be detrimental to the long-term physical health and well-being of patients, increasing the likelihood of treatment non-adherence and relapse. Evidence for some more recent therapeutic options, including lurasidone and cariprazine, suggests that patients' symptoms can be effectively managed without compromising their physical health. In addition, novel agents targeting alternative neurotransmitter pathways and inflammatory processes (such as ketamine and $\mathrm{N}$-acetyl cysteine) are emerging as promising potential options for the treatment of bipolar depression in the future.

Keywords: antidepressant, atypical antipsychotic, bipolar depression, bipolar disorder, pharmacotherapy

\section{Introduction}

Depressive symptoms predominate in the clinical course of both bipolar I disorder ${ }^{1}$ and bipolar II disorder, ${ }^{2}$ accounting for much of the morbidity, mortality and impaired quality of life associated with these conditions. ${ }^{3-5}$ While depressive symptoms are three times more frequent than manic/hypomanic symptoms in bipolar I disorder, depression accounts for $>90 \%$ of patients' symptomatology in bipolar II disorder. ${ }^{1,2}$ Suicidality further complicates the depressive presentation of the disease as suicide rates in bipolar disorder are approximately 10 times greater than the general population and depressive episodes and mixed states carry the highest risk for suicidal behavior. ${ }^{6,7}$ In addition to these, high suicide rates in bipolar disorder patients could pose a risk to their family and friends as their emotional turmoil may last a long time and, in some cases, may end with their own suicide. ${ }^{8}$ The literature on the neurobiology of suicide in bipolar disorder is also ambiguous which makes it difficult for clinicians to take preventative measures. ${ }^{6}$ Most of the studies on suicide risk have not included solely bipolar disorder samples or have focused on genetic, cell signaling, neurotransmitter system and neuroimaging measures, which are not a part of daily clinical 
practice. ${ }^{6,9}$ However, there are also studies looking at the relationship between routine clinical measures and suicide risk in mixed psychiatric samples including bipolar disorder patients that showed higher levels of testosterone, lower levels of cholesterol, triglycerides, free triiodothyronine and prolactin could predict suicide attempts. ${ }^{9,10}$

The identification, diagnosis and management of bipolar depression are particularly challenging, since bipolar depression and major depressive disorder (MDD) share certain symptoms, and misdiagnosis leads to inappropriate treatment and poor outcomes. ${ }^{11}$ In particular, bipolar depression generally responds poorly to traditional antidepressants, which may also induce a switch to mania and/or cause rapid cycling over the long term. ${ }^{12}$ Management of bipolar depression is further complicated by disease- and treatment-related factors, including cardiometabolic problems and immunological abnormalities, which contribute to a substantial reduction in the life expectancy of patients. ${ }^{13-15}$

Pharmacological treatments for bipolar depression are currently limited, although new therapeutic options are emerging, and guidelines vary greatly in terms of the types of pharmacological therapies recommended. ${ }^{16-22}$ Canadian Network for Mood and Anxiety Treatments and International Society for Bipolar Disorders guidelines (2018) recommend quetiapine, lurasidone + lithium/valproic acid, lithium, lamotrigine, lurasidone and adjunctive lamotrigine, ${ }^{16}$ whereas, British Association for Psychopharmacology guidelines (2016) endorse quetiapine, lurasidone or olanzapine as first-line treatments for acute bipolar depression. ${ }^{17}$ On the other hand, National Institute for Health and Care Excellence guidelines (2018) recommend olanzapine + fluoxetine, or quetiapine, ${ }^{18}$ while the World Federation of Societies of Biological Psychiatry $(2010)^{19}$ and German S3 (2012) guidelines ${ }^{20}$ only include quetiapine as a first-line agent for the acute treatment of bipolar depression. Finally, the Swiss Society for Bipolar Disorder (2015) recommends monotherapy with lithium (as well as quetiapine/quetiapine XR and lamotrigine), ${ }^{21}$ whilst the Royal Australian and New Zealand College of Psychiatrists clinical practice guidelines (2015) classify quetiapine, lurasidone, olanzapine, lithium, lamotrigine and valproate as first-line therapies for the treatment of bipolar depression. $^{22}$

Correct choice of treatment for the individual patient is essential, not only to effectively manage their symptoms but also to ensure that their physical health is not compromised by potential adverse effects of long-term treatment. The objectives of this article are to outline current evidence for pharmacological treatment options for bipolar depression and the implications of this evidence for everyday clinical practice.

\section{Pharmacological Treatment of Bipolar Depression: Available Evidence}

The variability between guidelines in the types of pharmacotherapies recommended reflects inconsistencies and gaps in the available evidence. A summary of this evidence is outlined here.

\section{Lithium}

The EMBOLDEN I study was a Phase 3, multicenter, randomized, double-blind, placebo-controlled trial in which approximately 800 patients in the acute phase of bipolar depression were randomized to receive 8 weeks of monotherapy with either lithium (600-1800 mg/day), one of two doses of quetiapine (300 or $600 \mathrm{mg} /$ day), or placebo. $^{23}$ Reductions in mean Montgomery-Åsberg Depression Rating Scale (MADRS) total score from baseline to Week 8 (the primary endpoint) were significantly greater for both doses of quetiapine versus placebo, but not for lithium versus placebo. ${ }^{23}$ Moreover, both doses of quetiapine were significantly more effective than lithium in reducing mean MADRS total score. ${ }^{23}$ Similarly, patients treated with quetiapine (both doses), but not lithium, achieved significantly greater MADRS response and remission rates versus placebo, and experienced significantly greater improvements versus placebo on the Hamilton Depression Rating Scale (HAM-D), Clinical Global Impression-Bipolar Version (CGI-BP) severity and change scores, and Hamilton Anxiety Rating Scale. ${ }^{23}$ The most common adverse event (AE) with lithium was nausea. $^{23}$ The lack of significant treatment effect with lithium observed in EMBOLDEN I may have resulted from only approximately two thirds of patients attaining a minimum lithium serum level of $0.6 \mathrm{mEq} / \mathrm{L}{ }^{23}$

An 8-week, open-label, randomized study demonstrated that lithium was significantly less effective than extended-release quetiapine in treating depressive symptoms and improving sleep quality in patients with bipolar depression. $^{24}$

Nevertheless, in the maintenance setting, there is clear evidence for lithium's efficacy in preventing depressive relapse. $^{25,26}$ Furthermore, lithium has been shown to be effectively decreasing the risk of suicide (Odds Ratio(OR) 
$0.13,95 \%$ Confidence Interval(CI): $0.03-0.66)$ and the risk of deaths from any cause (OR $0.38,95 \%$ CI: $0.15-0.95$ ) compared to placebo in mood disorders. ${ }^{27}$

\section{Valproate}

A meta-analysis of 4 randomized, double-blind and placebo-controlled trials with a total sample of 142 participants showed that valproate monotherapy was superior to placebo in treating acute bipolar depression. ${ }^{28}$ The patients on valproate were significantly more likely to meet the response (Relative $\operatorname{Risk}(R R)=2.10, p=0.02$ ) and the remission $(R R=1.61, p=0.04)$ criteria than those on placebo. ${ }^{28}$ The mean response rate was $39.3 \%$ for the patients who were prescribed valproate compared to $17.5 \%$ for the patients prescribed placebo. The mean remission rates were $40.6 \%$ and $24.3 \%$ for the patients on valproate and placebo, respectively. ${ }^{28}$ The rates for trial completion $(\mathrm{RR}=1.13, \mathrm{p}=0.40)$ and discontinuation due to side effects $(\mathrm{RR}=1.44, \mathrm{p}=0.72)$ were not significantly different between valproate and placebo. ${ }^{28}$

Although the results of this meta-analysis are promising, it needs to be noted that all trials included in this meta-analysis had small sample sizes and well-designed clinical trials with large sample sizes are needed to confirm these findings. ${ }^{28}$

A major consideration in the use of valproate is its teratogenic potential during pregnancy. ${ }^{29}$

\section{Antidepressants}

A systematic review and meta-analysis of 12 randomized controlled trials of antidepressants in the short-term treatment of bipolar depression, which included data from over 1000 patients, concluded that antidepressants are effective in the short-term treatment of bipolar depression. ${ }^{30}$ It also showed that a switch to mania is not commonly observed with short-term treatment (3.8\% event rate for antidepressants vs $4.7 \%$ for placebo), although the risk is higher with tricyclic antidepressants $(10 \%)$ than with all other antidepressants $(3.2 \%){ }^{30}$

On the other hand, the largest randomized, doubleblind, placebo-controlled trial of antidepressants for the treatment of acute bipolar depression, performed as part of the Systematic Treatment Enhancement Program for Bipolar Disorder (STEP-BD), found no differences in efficacy between antidepressant therapy and placebo as an adjunct to a mood stabilizer over a treatment period of up to 6 months (Figure 1). ${ }^{31}$ The risk of a switch to mania was found to be similar for antidepressant therapy and placebo. ${ }^{31}$ Furthermore, a more recent meta-analysis of six randomized controlled trials of antidepressants for the treatment of acute bipolar depression $(<16$ weeks) demonstrated that antidepressants were not statistically superior to placebo or other current standard treatments for bipolar depression and they did not increase the risk of a switch to mania in the acute setting. ${ }^{32}$ Other studies have demonstrated that the risk of a switch to mania varies

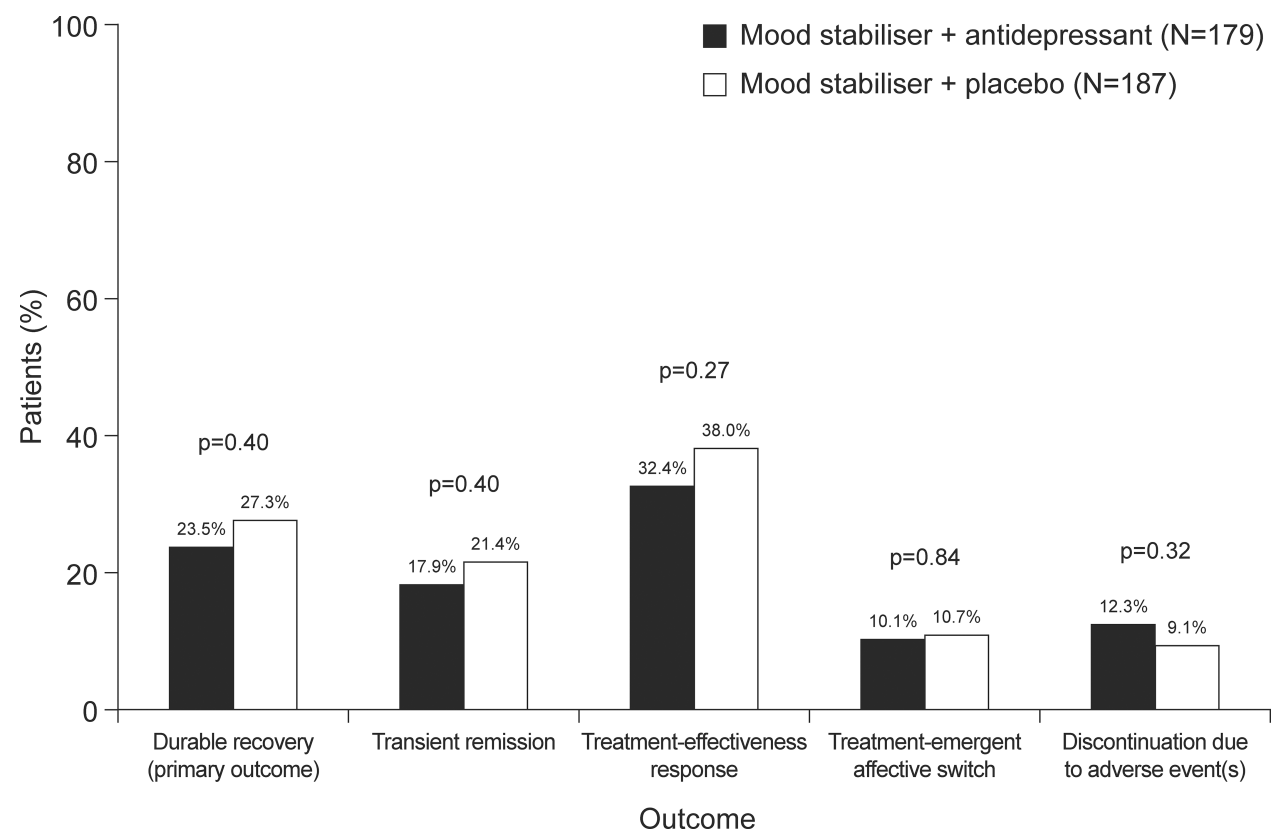

Figure I Outcomes according to treatment group in the Systematic Treatment Enhancement Program for Bipolar Disorder (STEP-BD). Data from Sachs et al. ${ }^{31}$ 
depending on study setting (being higher in retrospective and cross-sectional studies than in randomized controlled trials and open prospective studies), ${ }^{12,33}$ which argues against a causal role of antidepressants in the development of manic episodes.

Overall, the possible risk of a switch to mania, together with equivocal evidence regarding efficacy, has led to recommendations for either a cautious approach to antidepressant use in bipolar depression or a total avoidance of antidepressant therapy in this setting. ${ }^{34-36}$ The exception to this is fluoxetine, which is approved as a combination therapy with olanzapine in the USA for the treatment of depressive episodes associated with bipolar I disorder ${ }^{37}$ (See Atypical antipsychotics section for further information).

\section{Lamotrigine}

As with antidepressants, evidence for the use of lamotrigine in bipolar depression is equivocal. Results from five doubleblind, placebo-controlled clinical trials demonstrated that lamotrigine monotherapy did not differ significantly from placebo on primary efficacy endpoints (17-item HAM-D or MADRS) in the acute treatment of bipolar depression. ${ }^{38}$ In one study, lamotrigine (50 or $200 \mathrm{mg} /$ day) was significantly superior to placebo on some secondary efficacy endpoints (including MADRS, Clinical Global Impressions-Severity [CGI-S] and CGI-Improvement), but only rarely separated significantly from placebo on secondary efficacy endpoints in the other studies. ${ }^{38}$ By contrast, other trials have demonstrated that lamotrigine was effective in the treatment of bipolar depression when used either as monotherapy or as an adjunct to mood stabilizer therapy in the acute and longer-term settings (Figure 2). ${ }^{39-41}$

An important consideration for the use of lamotrigine is its potential for causing serious adverse skin reactions, ${ }^{42}$ although this did not emerge as a common problem in trials of the drug for bipolar depression in the acute setting. ${ }^{38}$ The risk of adverse skin reactions may be minimized by initiating lamotrigine at a relatively low dose and up-titrating very slowly. ${ }^{21}$

\section{Atypical Antipsychotics}

First-generation antipsychotics have been shown to be ineffective in the treatment of bipolar depression; indeed, continued use of perphenazine as adjunctive therapy to a mood stabilizer following remission from an acute manic episode was found to shorten time to depressive relapse and increase rates of dysphoria, depressive symptoms and extrapyramidal symptoms, in comparison with placebo. ${ }^{43}$

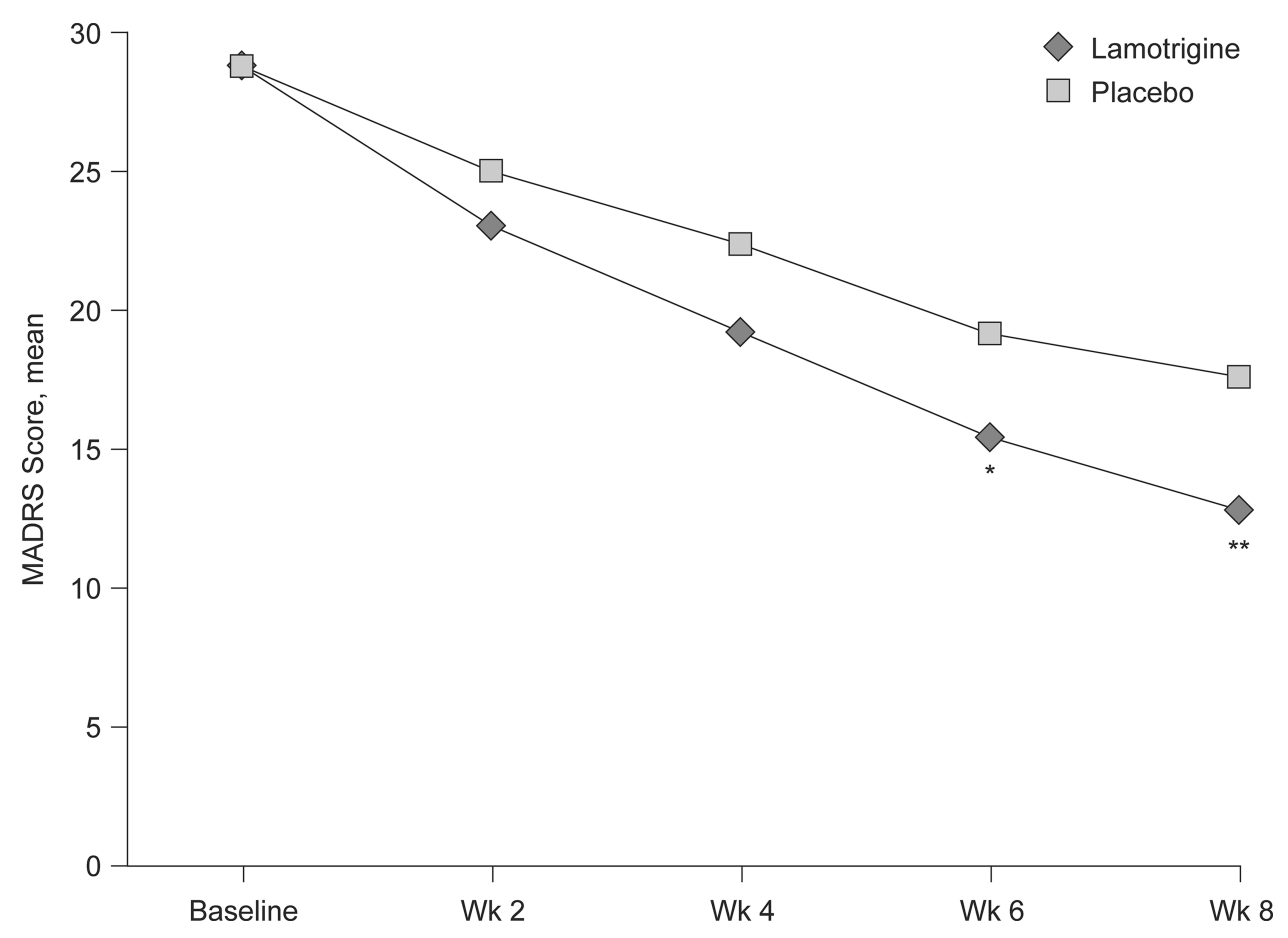

Figure 2 MADRS total score over 8 weeks of double-blind treatment with lamotrigine (titrated to $200 \mathrm{mg} /$ day) or placebo in the LamLit study. ${ }^{\mathrm{p}}=0.03 \mathrm{I}$ versus placebo; ** $_{\mathrm{p}}=0.006$ versus placebo. (MADRS, Montgomery-Åsberg Depression Rating Scale; Wk, week). van der Loos ML, Mulder PG, Hartong EG, et al. Efficacy and safety of lamotrigine as add-on treatment to lithium in bipolar depression: a multicenter, double-blind, placebo-controlled trial. J Clin Psychiatry. 2009;70(2):223-23I,. Copyright 2009, Physicians Postgraduate Press. Reprinted by permission. ${ }^{40}$ 
Several atypical antipsychotics have been investigated for the treatment of bipolar depression, but quetiapine is currently the only antipsychotic to be approved for this condition in Europe. ${ }^{44}$ In the USA, the Food and Drug Administration has approved olanzapine-fluoxetine combination therapy for the treatment of depressive episodes associated with bipolar I disorder ${ }^{37}$ and lurasidone for the treatment of bipolar depression, as monotherapy or as adjunctive therapy to lithium or valproate. ${ }^{45}$ An important issue to consider when assessing the potential use of atypical antipsychotics is the great variability between agents in their propensity for causing adverse cardiometabolic effects, including sudden cardiac death, weight gain, dyslipidemia and glucose dysregulation. ${ }^{46,47}$

\section{Quetiapine}

Among the approved treatments for bipolar depression, quetiapine has the largest evidence base. A systematic review and meta-analysis of eleven randomized controlled trials that compared quetiapine with placebo or active treatments in patients with acute bipolar depression demonstrated that quetiapine monotherapy (300 or $600 \mathrm{mg} /$ day) is effective for acute bipolar depression and the prevention of mania/hypomania switching. ${ }^{48}$ Compared with placebo, the mean difference $(95 \% \mathrm{CI})$ for average change in depressive scores (MADRS or Children's Depression Rating Scale, Revised) was $-4.66(-5.59$ to -3.73$) .{ }^{48}$ For quetiapine versus placebo, the risk ratios (RR) $(95 \% \mathrm{CI})$ for response rate at endpoint, remission rate at endpoint and treatment-emergent mania were $1.31(1.23-1.40), 1.36$ $(1.24-1.49)$ and $0.58 \quad(0.37-0.91)$, respectively. ${ }^{48}$ Quetiapine treatment was also associated with significant improvements in clinical global impression, quality of life, sleep quality, anxiety and functioning. ${ }^{48}$

Compared with placebo, quetiapine caused more AEs of somnolence (RR, 3.74; 95\% CI, 2.86-4.90), dry mouth (RR, 3.65 ; 95\% CI, 3.04-4.40), sedation (RR, 3.32; 95\% CI, 2.714.06), extrapyramidal side effects (RR, 2.77 ; $95 \% \mathrm{CI}, 2.12$ 3.62), increased appetite (RR, 2.81; 95\% CI, 1.58-5.01), weight gain (RR, 2.33; 95\% CI, 1.34-4.03), dizziness (RR, 2.18; 95\% CI, 1.73-2.74), constipation (RR, 2.05; 95\% CI, $1.50-2.81)$ and fatigue (RR, $1.57 ; 95 \% \mathrm{CI}, 1.16-2.13){ }^{48}$

\section{Olanzapine-Fluoxetine Combination Therapy}

In the 8-week, randomized, double-blind, placebo-controlled United States registration trial, combined olanzapine-fluoxetine treatment ( 6 and 25, 6 and 50, or 12 and $50 \mathrm{mg} /$ day olanzapine and fluoxetine, respectively) was shown to be significantly more effective than both placebo and olanzapine alone $(5-20 \mathrm{mg} /$ day) in the treatment of bipolar I depression, without increasing the risk of developing manic symptoms (Figure 3). ${ }^{49}$ At Week 8, MADRS total scores were lower than at baseline by $11.9,15.0$, and 18.5 points in the placebo, olanzapine, and olanzapine-fluoxetine groups, respectively.${ }^{49}$ Corresponding values for remission were $24.5 \%, 32.8 \%$ and $48.8 \%$, respectively, and, for treatment-emergent mania, they were $6.7 \%, 5.7 \%$ and $6.4 \%$, respectively. ${ }^{49}$

AEs were similar for olanzapine and olanzapine-fluoxetine, except that diarrhea and nausea were significantly more common with olanzapine-fluoxetine than with olanzapine. ${ }^{49}$ The most frequently reported AEs with olanzapine-fluoxetine (occurring in $\geq 10 \%$ of patients and $\geq 2$ times more frequently than with placebo) were weight gain $(17.4 \%$ vs $2.7 \%$; $<0.001)$, increased appetite $(12.8 \%$ vs $5.0 \% ; \mathrm{p}<0.001)$, dry mouth $(16.3 \%$ vs $6.1 \% ; \mathrm{p}=0.02)$, asthenia $(12.8 \%$ vs $3.2 \% ; \mathrm{p}<0.001)$ and diarrhea $(18.6 \%$ vs $6.6 \% ; \mathrm{p}=0.001){ }^{49}$

A subsequent analysis of data from this trial demonstrated that the number needed to harm $(\mathrm{NNH})$ for clinically significant weight gain (defined as $\geq 7 \%$ increase from baseline) was six for olanzapine-fluoxetine versus placebo. ${ }^{50}$

\section{Lurasidone}

The effectiveness of lurasidone in bipolar depression has been investigated in the Program to Evaluate the Antidepressant Impact of Lurasidone (PREVAIL). PREVAIL 1 was a 6-week, randomized, double-blind, placebo-controlled trial that evaluated lurasidone's efficacy as adjunctive therapy to lithium or valproate. ${ }^{51}$ Lurasidone (20-120 mg/day), compared with placebo, significantly reduced mean MADRS total score (-17.1 vs -13.5 ; effect size, 0.34) and CGI-Bipolar Version (CGI-BP) depression severity score $(-1.96$ vs -1.51 ; effect size, 0.36$)$ at week $6 .{ }^{51}$ Lurasidone treatment also resulted in significantly greater improvements in anxiety symptoms and patientreported measures of quality of life and functionality. ${ }^{51}$ The incidence of treatment-emergent mania was similar for lurasidone versus placebo (1.1\% vs $1.2 \%) .{ }^{51}$ The only AE reported by $\geq 5 \%$ of patients in the lurasidone group and $\geq 2$-times more frequently than with placebo was somnolence $(8.7 \%$ vs $4.3 \%) .{ }^{51}$ Akathisia occurred in $7.7 \%$ of patients treated with lurasidone and $4.3 \%$ of those treated with placebo and the incidence of extrapyramidal events was $15.3 \%$ versus $9.8 \%{ }^{51}$

PREVAIL 2 was a 6-week, randomized, double-blind, placebo-controlled trial, which demonstrated that 


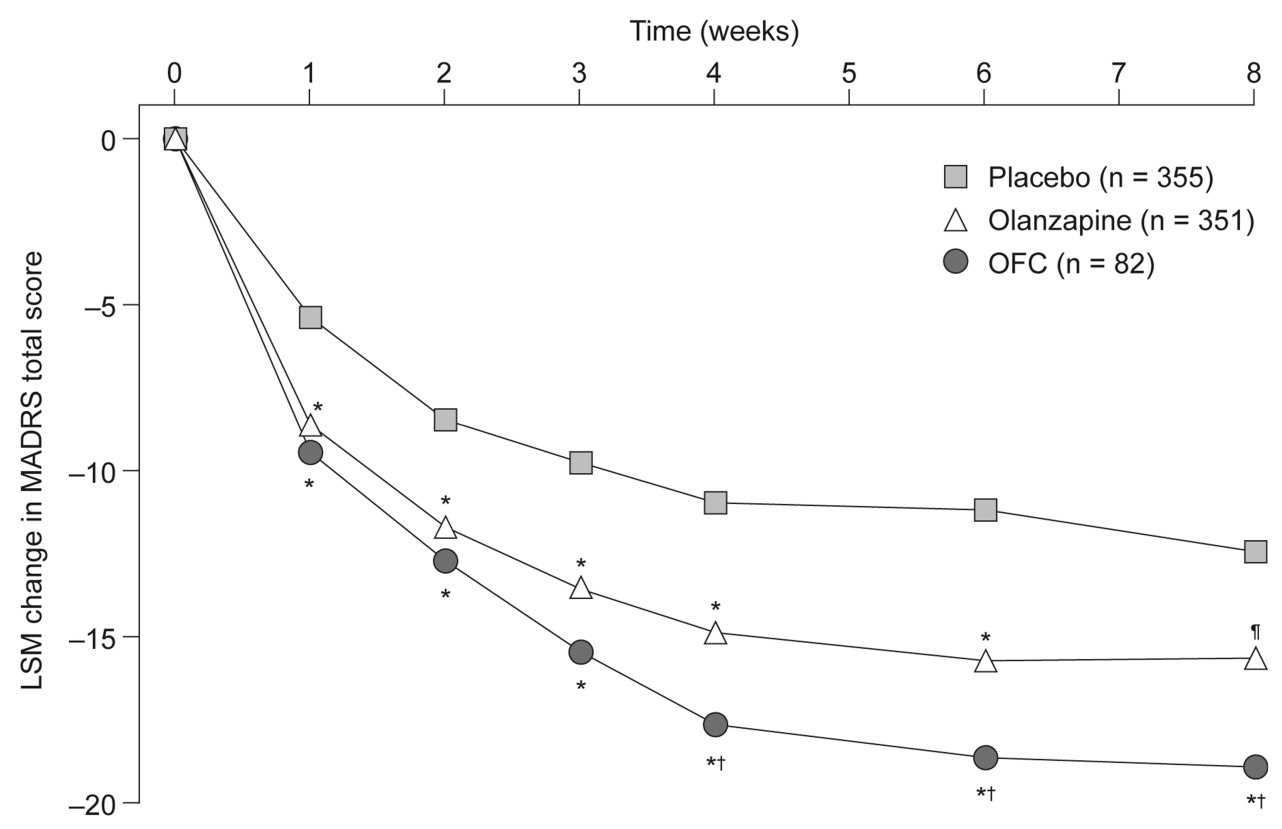

Figure 3 MADRS total score over 8 weeks of treatment with olanzapine-fluoxetine combination therapy ( 6 and 25,6 and 50 , or I2 and $50 \mathrm{mg} /$ day olanzapine and fluoxetine, respectively), compared with olanzapine alone $\left(5-20 \mathrm{mg} /\right.$ day) and placebo. ${ }^{*} p<0.00 \mathrm{I}$ versus placebo; ${ }^{\dagger} \mathrm{p}<0.05$ versus olanzapine; ${ }^{\top} \mathrm{p}=0.002$ versus placebo. (LSM, least squares mean; MADRS, Montgomery-Åsberg Depression Rating Scale; OFC, olanzapine-fluoxetine combination). Reproduced with permission from Tohen M, Vieta E, Calabrese J, et al. Efficacy of olanzapine and olanzapine-fluoxetine combination in the treatment of bipolar I depression. Arch Gen Psychiatry. 2003;60(II):I079-1088. Copyright (2003) American Medical Association. All rights reserved. ${ }^{49}$

lurasidone monotherapy was significantly more effective than placebo in decreasing MADRS total and CGI-BP depression severity scores, with progressive improvement observed from week 2 onwards (Figure 4). ${ }^{52}$ Mean changes in MADRS total scores from baseline to week 6 for lurasidone $20-60 \mathrm{mg}$ /day, lurasidone $80-120 \mathrm{mg}$ /day and placebo were $-15.4,-15.4$ and -10.7 , respectively (effect sizes for both lurasidone groups vs placebo, 0.51). ${ }^{52}$ Corresponding values for mean changes in CGIBP depression severity scores were -1.8 (effect size, 0.61 ), -1.7 (effect size, 0.50 ) and -1.1 , respectively. ${ }^{52}$ As in the adjunctive setting, there were also significant improvements in both lurasidone groups, compared with placebo, in anxiety symptoms and patient-reported measures of quality of life and functionality. ${ }^{52}$ Treatment-emergent mania occurred in $3.7 \%, 1.9 \%$ and $1.9 \%$ of patients in the lurasidone $20-60 \mathrm{mg}$, lurasidone $80-120 \mathrm{mg}$ and placebo groups, respectively. ${ }^{52}$ The most frequently reported AEs with lurasidone ( $\geq 5 \%$ of patients in either group and $\geq 2$-times more frequent than with placebo) were nausea (10.4\%, $17.4 \%$ and $7.7 \%$ for lurasidone $20-60 \mathrm{mg}$, lurasidone $80-120 \mathrm{mg}$ and placebo groups, respectively), akathisia (7.9\%, 10.8\% and 2.4\%), extrapyramidal events (4.9\%, $9.0 \%$ and $2.4 \%)$, sedation $(3.0 \%, 7.2 \%$ and $1.8 \%)$ and vomiting $(2.4 \%, 6.0 \%$ and $1.8 \%){ }^{52}$
PREVAIL 3 was another 6-week, randomized, doubleblind, placebo-controlled trial that evaluated lurasidone's efficacy as adjunctive therapy to lithium or valproate. ${ }^{53}$ Unlike PREVAIL 1, which only included patients treated retrospectively with lithium or valproate, ${ }^{51}$ PREVAIL 3 included patients treated either retrospectively or prospectively with a mood stabilizer. ${ }^{53}$ In PREVAIL 3, improvements in MADRS total score and CGI-BP depression severity score from baseline to week 6 were not significant for lurasidone versus placebo, although there was a significant separation in favor of lurasidone versus placebo on MADRS total score from weeks $2-5$ and on CGI-BP depression severity score from weeks $3-5 .^{53}$ A preplanned analysis demonstrated that improvement in MADRS total score was significantly greater in patients treated with a mood stabilizer retrospectively versus prospectively. ${ }^{53}$ The most frequently reported AEs with lurasidone ( $\geq 5 \%$ of patients and $\geq 2$-times more frequent than with placebo) were akathisia (14.1\% vs $5.3 \%)$ and somnolence $(11.9 \%$ vs $4.7 \%){ }^{53}$ The incidence of extrapyramidal events was $12.4 \%$ in patients treated with lurasidone versus $7.6 \%$ in patients treated with placebo. ${ }^{53} \mathrm{In}$ all the PREVAIL trials, lurasidone treatment was associated with minimal changes in weight, lipids, and measures of glycemic control. ${ }^{51-53}$ 


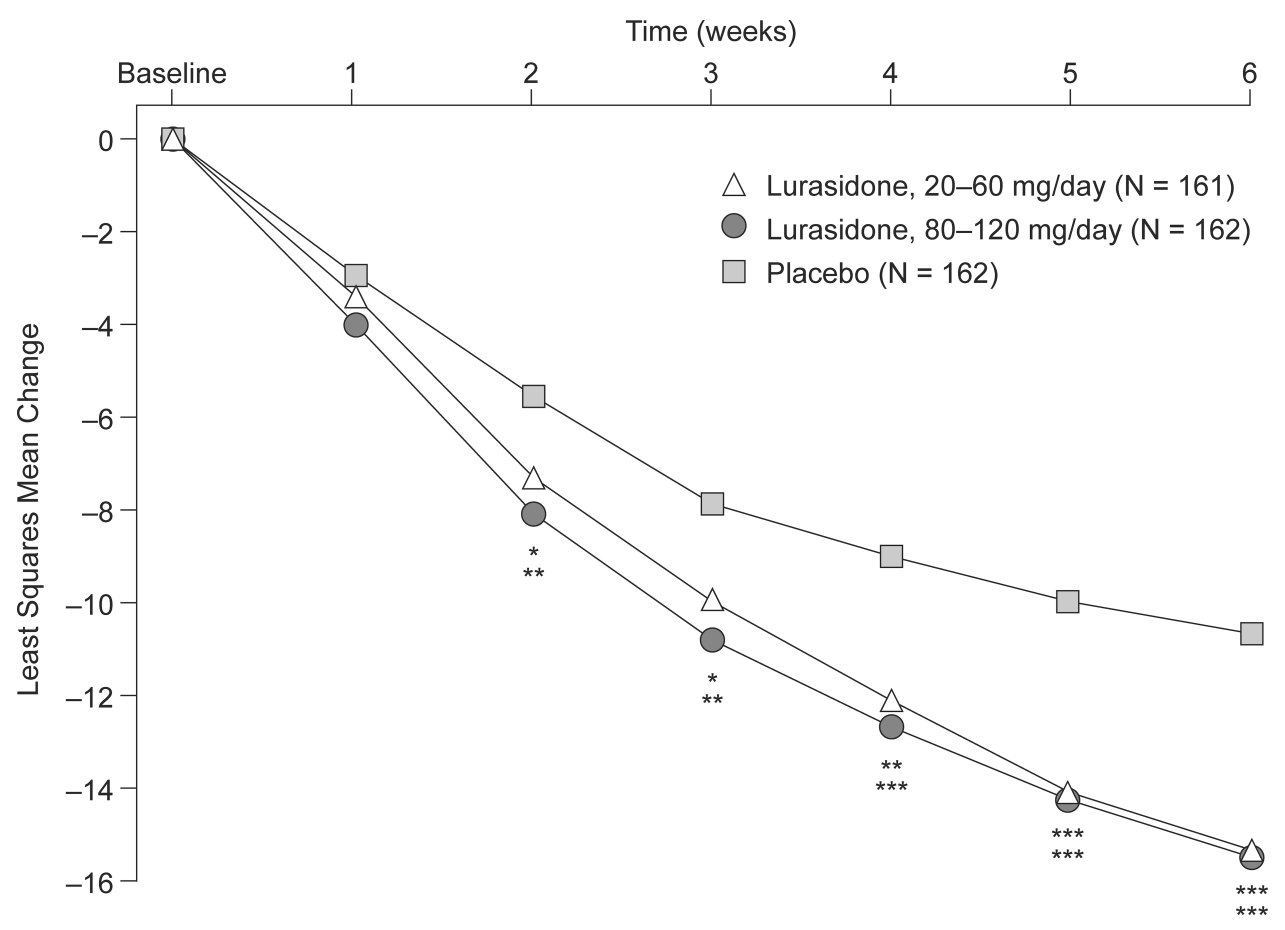

Figure 4 MADRS total score following 6 weeks of treatment with lurasidone monotherapy versus placebo in PREVAIL 2 . *p<0.05 versus placebo; **p<0.0I versus placebo; *** $\mathrm{p}<0.001$ versus placebo. (MADRS, Montgomery-Åsberg Depression Rating Scale.) Loebel A, Cucchiaro J, Silva R, et al. Lurasidone monotherapy in the treatment of bipolar I depression: a randomized, double-blind, placebo-controlled study. Am J Psychiatry. 20I4;17I(2):I60-I68. Reprinted with permission from the American Journal of Psychiatry, (Copyright (C 2014). American Psychiatric Association. All Rights Reserved. ${ }^{52}$

A post hoc analysis of PREVAIL 1 and 2, based on number needed to treat (NNT) and NNH analyses, revealed that the benefits associated with lurasidone treatment (in terms of response and remission) were comparable to those of quetiapine and olanzapine-fluoxetine, with less risk of sedation, compared with quetiapine and less risk of clinically significant weight gain compared with olanzapinefluoxetine (Table 1) ${ }^{54}$ Lurasidone is currently not approved for the treatment of bipolar depression in Europe.

\section{Aripiprazole}

The effectiveness of aripiprazole monotherapy (5-30 mg/day) in bipolar depression was evaluated in two identically designed, 8-week, multicenter, randomized, double-blind, placebo-controlled trials. ${ }^{55}$ Statistically significant differences were observed during Weeks 1 to 6 on both MADRS total score (the primary endpoint) and CGI-BP depression severity score (a key secondary endpoint); however, aripiprazole was not significantly superior to placebo at endpoint for either of these outcome measures. ${ }^{55}$ The most frequently reported AEs with aripiprazole ( $\geq 10 \%$ of aripiprazole patients in either study and $\geq 2$-times more frequent than with placebo) were akathisia, insomnia, nausea, fatigue, restlessness and dry mouth. ${ }^{55}$ In both studies, there were no clinically significant differences between aripiprazole and placebo in terms of serum prolactin, fasting serum glucose, lipid levels and weight gain. ${ }^{55}$

A post hoc analysis of the two monotherapy trials, based on baseline severity of core depressive symptoms, suggested that aripiprazole may provide some improvements in core symptoms of depression in patients who are severely depressed (Bech-6 Total score $>15$ ), although statistical significance was not demonstrated. ${ }^{56}$ In the long-term setting, aripiprazole has been shown to be more effective than placebo in delaying manic relapse, but not depressive relapse, when administered as either monotherapy ${ }^{57}$ or as adjunctive therapy with a mood stabilizer. $^{58}$

\section{Cariprazine}

Cariprazine is an atypical antipsychotic that acts as a partial agonist at dopamine $\mathrm{D}_{2}$ and $\mathrm{D}_{3}$ receptors (with higher binding affinity for $\mathrm{D}_{3}$ ) and serotonin $5-\mathrm{HT}_{1 \mathrm{~A}}$ and $5-\mathrm{HT}_{2 \mathrm{~A}}$ receptors. ${ }^{59}$ In a Phase 2, 8-week, randomized, double-blind, placebo-controlled, parallel-group, fixed-dose trial, conducted in adult patients with bipolar I disorder experiencing a current major depressive episode, treatment with cariprazine $1.5 \mathrm{mg}$ /day resulted in significantly greater improvement than placebo on change from baseline to Week 6 in MADRS total score (the primary endpoint), whereas treatment with cariprazine $3.0 \mathrm{mg} /$ 
Table I Summary of NNT (MADRS Responder; MADRS Remitter) and NNH (Clinically Significant Weight Gain; Somnolence) Values for Adjunctive Lurasidone and Lurasidone Monotherapy, Compared with Quetiapine Monotherapy and Olanzapine-Fluoxetine Combination Monotherapy. Lurasidone Data are Pooled from the PREVAIL I and II Trials

\begin{tabular}{|c|c|c|c|c|c|}
\hline Parameter & $\begin{array}{l}\text { Adjunctive } \\
\text { Lurasidone } \\
20-120 \mathrm{mg} / \text { day }\end{array}$ & $\begin{array}{l}\text { Lurasidone } \\
\text { Monotherapy } \\
\text { 20-60 mg/day }\end{array}$ & $\begin{array}{l}\text { Lurasidone } \\
\text { Monotherapy } \\
80-120 \mathrm{mg} / \text { day }\end{array}$ & $\begin{array}{l}\text { Quetiapine IR or } \\
\text { XR } \\
\text { Monotherapy }\end{array}$ & $\begin{array}{l}\text { Olanzapine-Fluoxetine } \\
\text { Combination } \\
\text { Monotherapy }\end{array}$ \\
\hline NNT MADRS response ${ }^{a}$ & 7 & 5 & 5 & 6 & 4 \\
\hline NNT MADRS remission ${ }^{\mathrm{b}}$ & 7 & 6 & 7 & 6 & 5 \\
\hline $\begin{array}{l}\text { NNH clinically relevant } \\
\text { weight gainc }\end{array}$ & 42 & 29 & 5550 & 16 & 6 \\
\hline NNH somnolence ${ }^{d}$ & 19 & 130 & 14 & $3^{\mathrm{e}}$ & NR \\
\hline
\end{tabular}

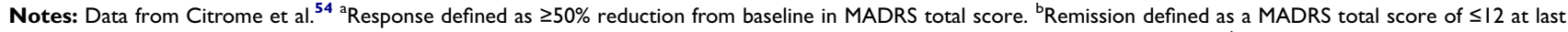
observation carried forward endpoint. ' Clinically significant weight gain defined as $\geq 7 \%$ increase from baseline in body weight. ${ }^{\mathrm{d}}$ Includes hypersomnia, sedation and

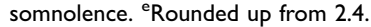

Abbreviations: IR, immediate release; MADRS, Montgomery-Åsberg Depression Rating Scale; NNH, number needed to harm; NNT, number needed to treat; NR, not recorded; $X R$, extended release.

day was not significantly superior to placebo when adjusted for multiple comparisons. ${ }^{60} \mathrm{~A}$ similar pattern of significance was observed on the CGI-S. ${ }^{60}$

In a subsequent Phase 3, 6-week, randomized, doubleblind, placebo-controlled, parallel-group, fixed-dose trial, conducted in adult patients with bipolar I depression, cariprazine 1.5 and $3.0 \mathrm{mg} /$ day were both significantly superior to placebo on change from baseline to Week 6 in MADRS total score (the primary endpoint): the least squares mean differences were -2.5 ( $95 \% \mathrm{CI},-4.6$ to -0.4 ; adjusted $\mathrm{p}=0.033$; effect size, $0.28)$ for cariprazine $1.5 \mathrm{mg} /$ day and $-3.0(95 \% \mathrm{CI},-5.1$ to -0.9 ; adjusted $\mathrm{p}=0.010$; effect size, 0.34 ) for cariprazine 3.0 $\mathrm{mg} /$ day ${ }^{61}$ Both cariprazine dosages were associated with lower CGI-S scores than placebo. ${ }^{61}$ The most frequently reported AEs with cariprazine ( $\geq 5 \%$ of patients and $\geq 2$-times more frequent than with placebo) were nausea $(0.6 \%, 3.8 \%$ and $9.1 \%$ for placebo, cariprazine $1.5 \mathrm{mg}$ /day and cariprazine $3.0 \mathrm{mg} /$ day, respectively), akathisia (3.2\%, $6.4 \%$ and $5.5 \%)$, dizziness $(1.9 \%, 5.1 \%$ and $3.6 \%)$ and sedation $(1.3 \%, 5.1 \%$ and 3.0\%). ${ }^{61}$ Mean changes in weight and metabolic parameters were comparable across groups and not considered clinically significant. ${ }^{61}$ Cariprazine is currently not approved for the treatment of bipolar depression in Europe.

\section{Novel Treatment Options}

Current treatment options for bipolar depression, such as atypical antipsychotics, generally target central dopaminergic and serotonergic systems. However, several novel therapeutic targets are emerging as potential alternative treatment approaches. These include ketamine, which is thought to exert antidepressant effects through antagonism of N-methylD-aspartate receptors and, possibly, by inhibiting the function of norepinephrine and serotonin transporters, ${ }^{62}$ and riluzole, a glutamatergic modulator that inhibits glutamate release and enhances glutamate reuptake, and additionally enhances $\alpha$ amino-3-hydroxy-5-methyl-4-isoxazolepropionic acid trafficking. ${ }^{63}$ Furthermore, the high prevalence of medical comorbidities in bipolar disorder, such as cardiovascular disease and immune dysfunction, has led to speculation that it may represent a "multi-system inflammatory disease", ${ }^{64}$ which has resulted in several anti-inflammatory agents being investigated as potential therapeutic options for bipolar depression, including $\mathrm{N}$-acetyl cysteine ${ }^{65}$ and the antibiotic minocycline. ${ }^{66}$ In addition, brexpiprazole, modafinil/armodafinil and pramipexole as well as triiodothyronine (T3) could be other promising agents in the treatment of bipolar depression. ${ }^{67-71} \mathrm{~A}$ summary of evidence for these and other novel treatment approaches for bipolar depression is outlined in Table 2 .

\section{Limitations of Article}

This article has attempted to provide an overview of current evidence for pharmacological treatment options for bipolar depression and a commentary on the implications of this evidence for everyday clinical practice. However, the evidence it includes was not collected via systematic review of the literature and its contents are therefore by no means definitive; rather, they represent the authors' opinions of the current treatment landscape for bipolar depression, based on their interpretation of published data and personal clinical experience.

\section{Summary}

Although depression predominates the clinical course of bipolar disorder, current treatment options for bipolar depression 
Table 2 Novel Treatments for Bipolar Depression

\begin{tabular}{|c|c|c|}
\hline Agent & Pharmacological Details & Summary of Evidence in Bipolar Depression \\
\hline Ketamine & $\begin{array}{l}\text { NMDA receptor antago- } \\
\text { nist; dissociative anesthetic } \\
\text { agent }{ }^{72} \\
\text { - Thought to exert antide- } \\
\text { pressant effects via NMDA } \\
\text { receptor antagonism and } \\
\text { possible inhibitory effects } \\
\text { on norepinephrine and } \\
\text { serotonin transporter } \\
\text { function }^{62}\end{array}$ & $\begin{array}{l}\text { - Several RCTs and open-label retrospective studies have demonstrated rapid improvement of } \\
\text { depression, suicidal ideation and anhedonia following single low (subanesthetic) intravenous } \\
\text { doses, compared with placebo }{ }^{73-78} \\
\text { - Response rate for depression was statistically significant versus placebo for up to approxi- } \\
\text { mately } 3 \text { days }{ }^{74,75} \\
\text { - Some evidence of improvement in fatigue for up } 2 \text { weeks following single intravenous dosing }{ }^{79} \\
\text { - AEs include dizziness, blurred vision, restlessness, nausea/vomiting and headache; AEs are } \\
\text { usually transient and mild; no serious AEs reported }{ }^{73,77,80} \\
\text { - Use may be limited by need for administration by an anesthesiologist and hospitalization post- } \\
\text { administration }{ }^{81} \\
\text { - Potential use as a longer-term treatment is currently unclear }{ }^{81}\end{array}$ \\
\hline $\begin{array}{l}\text { Modafinil/ } \\
\text { armodafinil }\end{array}$ & $\begin{array}{l}\text { Wakefulness-promoting, } \\
\text { low-affinity dopamine } \\
\text { transport inhibitor }{ }^{68} \\
\text { - Armodafinil is the active } \\
\text { R-enantiomer of } \\
\text { modafinil }^{68}\end{array}$ & $\begin{array}{l}\text { - A 6-week placebo-controlled study demonstrated that modafinil added to a mood stabilizer } \pm \\
\text { an antidepressant resulted in significantly greater response and remission rates than placebo }{ }^{69} \\
\circ \text { Incidence of treatment-emergent hypomania/mania was similar between groups } \\
\text { - Three 8-week studies of armodafinil as an adjunctive treatment in bipolar depression have been } \\
\text { inconsistent in their findings }{ }^{68,82,83} \\
\text { In a 6-month, open-label extension study of patients completing these trials, armodafinil } \\
\text { improved depressive symptoms and patient functioning and was generally well tolerated }{ }^{84} \\
\text { o Most frequently reported AEs were headache, insomnia and anxiety }\end{array}$ \\
\hline Pramipexole & - $\mathrm{D}_{2} / \mathrm{D}_{3}$ receptor agonist ${ }^{70}$ & $\begin{array}{l}\text { - Two small, } 6 \text {-week RCTs have investigated the effectiveness of pramipexole as an adjunct to } \\
\text { mood stabilizers in bipolar depression }(n=22 ; n=21)^{70,85} \\
\text { In one, improvements from baseline in HAM-D score and CGI severity were significantly } \\
\text { greater with pramipexole versus placebo, as was HAM-D responder rate } \\
\text { - In the other, ANOVA for MADRS total score showed a significant treatment effect, and } \\
\text { MADRS responder rate was significantly higher with pramipexole versus placebo }{ }^{85} \\
\text { - In both trials, pramipexole was well tolerated and not associated with an increased incidence of } \\
\text { hypomania/mania } \\
\text { - Additional limited evidence supporting the use of adjunctive pramipexole for bipolar depres- } \\
\text { sion from open studies } \\
86,87\end{array}$ \\
\hline Riluzole & $\begin{array}{l}\text { - Inhibits glutamate release } \\
\text { and enhances glutamate } \\
\text { reuptake and AMPA } \\
\text { trafficking } \\
\text { - Inhibits voltage-dependent } \\
\text { sodium channels }^{88}\end{array}$ & $\begin{array}{l}\text { - In an 8-week, open-label study conducted in } 14 \text { acutely depressed bipolar patients (MADRS } \\
\geq 20 \text { ), riluzole added to existing lithium treatment resulted in significant improvement in } \\
\text { MADRS total score and no switch to hypomania/mania was observed } \\
\text { - Interim analysis of an } 8 \text {-week, placebo-controlled RCT of riluzole monotherapy, conducted in } \\
\text { I9 patients with bipolar depression, demonstrated that there were no significant differences on } \\
\text { MADRS or HAM-D scores for riluzole versus placebo, and anxiety scores (HAM-A) were } \\
\text { significantly lower for placebo versus riluzole } \\
\text { The trial was subsequently stopped }^{90}\end{array}$ \\
\hline $\begin{array}{l}\mathrm{N} \text {-acetyl } \\
\text { cysteine }\end{array}$ & $\begin{array}{l}\text { - Acetyl derivative of the } \\
\text { amino acid cysteine }{ }^{91} \\
\text { - Increases glutathione levels } \\
\text { in the brain, which may } \\
\text { decrease oxidative stress } \\
\text { and inflammation }\end{array}$ & $\begin{array}{l}\text { - In a } 24 \text {-week, multicenter RCT, conducted in patients with bipolar disorder in the maintenance } \\
\text { phase, } \mathrm{N} \text {-acetyl cysteine (as an adjunct to usual treatment) resulted in significant improvements } \\
\text { on MADRS versus placebo } \\
\text { - A subsequent RCT of } \mathrm{N} \text {-acetyl cysteine as an adjunctive maintenance treatment for bipolar } \\
\text { disorder yielded inconclusive results due to low event rates }{ }^{93} \\
\text { - A } 20 \text {-week placebo-controlled RCT will assess the effects of adjunctive } \mathrm{N} \text {-acetyl cysteine } \\
\text { treatment on depressive symptoms in patients diagnosed with bipolar depression }{ }^{94} \\
\text { Primary outcome will be mean change from baseline on MADRS }\end{array}$ \\
\hline
\end{tabular}

(Continued) 
Table 2 (Continued).

\begin{tabular}{|c|c|c|}
\hline Agent & Pharmacological Details & Summary of Evidence in Bipolar Depression \\
\hline $\begin{array}{l}\text { Other anti- } \\
\text { inflammatory } \\
\text { agents }\end{array}$ & $\begin{array}{l}\text { Bipolar disorder has been } \\
\text { proposed to be a multisys- } \\
\text { temic inflammatory disease } \\
\text { due to high levels of } \\
\text { comorbid medical condi- } \\
\text { tions and adjunctive anti- } \\
\text { inflammatory medication } \\
\text { may, therefore, be a ratio- } \\
\text { nale therapeutic strategy }\end{array}$ & 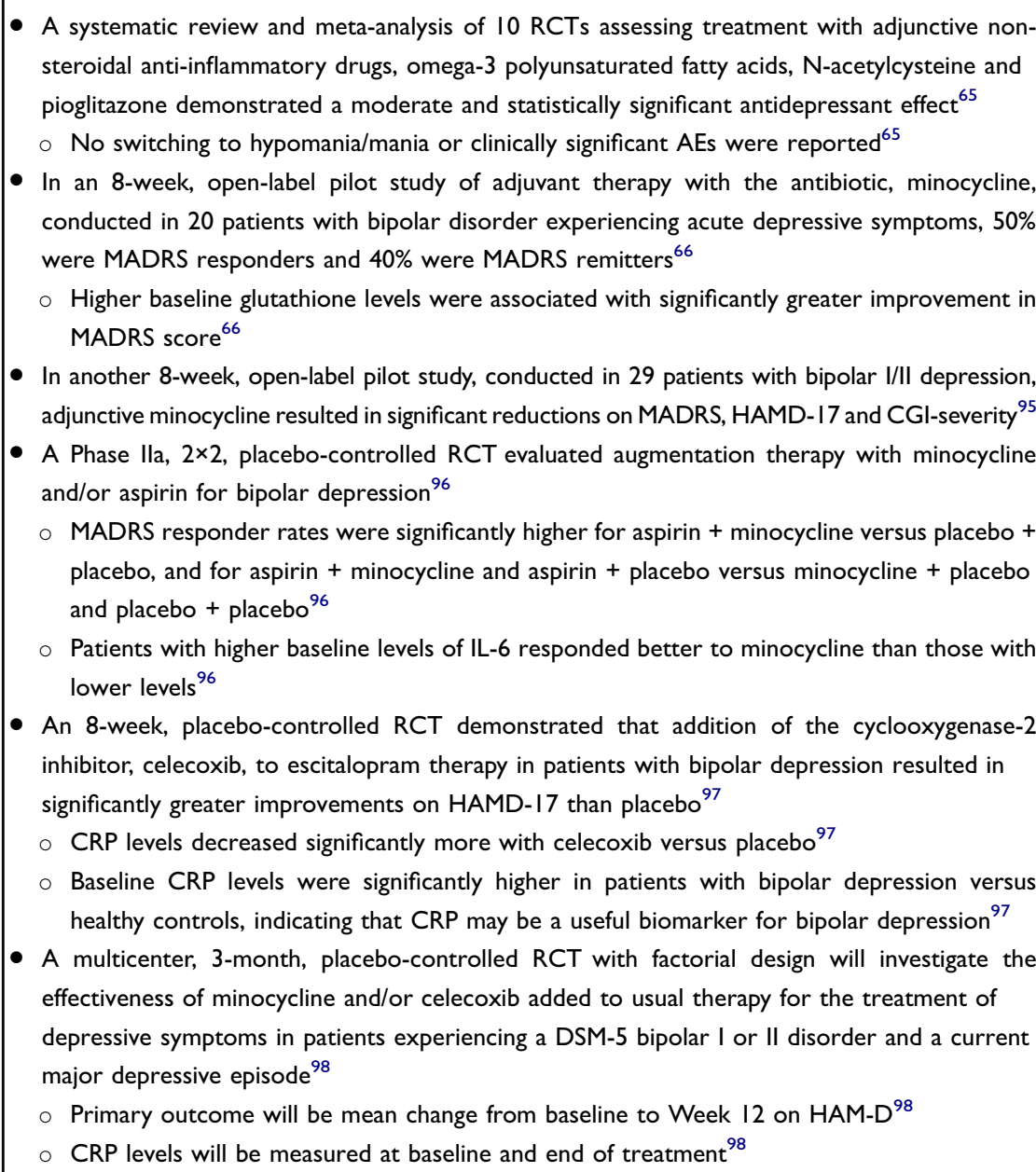 \\
\hline T3 & $\begin{array}{l}\text { - Active form of thyroid hor- } \\
\text { mone thyroxine } \\
\text { - The thyroid hormones } \\
\text { affect the function of sero- } \\
\text { tonin, catecholamine and } \\
\text { dopamine systems in the } \\
\text { brain }^{67}\end{array}$ & $\begin{array}{l}\text { - In one retrospective chart review, } 84 \% \text { of the patients with bipolar disorder }(n=159) \text { who were } \\
\text { treatment-resistant showed improvement with add-on T3 and approximately one third (33\%) } \\
\text { went into remission } \\
\text { - In a comparative study, bipolar subgroup revealed a mean of } 15 \text { points decrease on the HAM-D } \\
\text { with T3 after I week compared to only } 6 \text { points in the control group } 100 \\
\text { - In an open-label study, add-on T3 treatment was effective in } 5 \text { out of the } 7 \text { patients (72\%) with } \\
\text { bipolar depression }{ }^{67}\end{array}$ \\
\hline Brexpiprazole & $\begin{array}{l}\text { - Serotonin and dopamine } \\
\text { receptor modulator } \\
\text { - Sub-nanomolar potency as } \\
\text { an antagonist at serotonin } \\
5-\mathrm{HT}_{2 \mathrm{~A}} \text { and adrenergic } \\
\alpha \mid \mathrm{I} \text { receptors } \\
\text { - } \\
\text { A partial agonist at seroto- } \\
\text { nin 5-HT } \mathrm{IA}_{\mathrm{A}} \text { and dopamine } \\
\mathrm{D}_{2} \text { receptors }\end{array}$ & $\begin{array}{l}\text { - In an open-label study, treatment with brexpiprazole } 4 \mathrm{mg} / \text { day for } 8 \text { weeks resulted in } \\
\text { decreases in MADRS total and Inventory of Depressive Symptomatology Self-report scores } \\
\text { at Weeks } 4 \text { and } 8 \text { in } 21 \text { patients with bipolar depression } \\
\text { - An increase in Quality of Life in Bipolar Disorder score from baseline to Week } 8 \text {, with no } \\
\text { significant changes in Young Mania Rating Scale and cognitive scores were also reported }\end{array}$ \\
\hline
\end{tabular}

Abbreviations: AE, adverse event; AMPA, $\alpha$-amino-3-hydroxy-5-methyl-4-isoxazolepropionic acid; ANOVA, analysis of variance; CGI, Clinical Global Impression; CRP, C-reactive protein; DSM-5, Diagnostic and Statistical Manual of Mental Disorders, 5th Edition; HAM-A, Hamilton Anxiety Rating Scale; HAM-D, Hamilton Depression Rating Scale; HAMD-17, 17-item Hamilton Depression Rating Scale; IL-6, interleukin-6; MADRS, Montgomery-Åsberg Depression Rating Scale; NMDA, N-methyl-D-aspartate; RCT, randomized controlled trial: $T 3$, triiodothyronine, $5-H T_{I A}$, serotonin IA receptor: $5 H T_{2 A}$, serotonin $2 A$ receptor. 
are limited; in particular, because traditional antidepressants have equivocal efficacy in bipolar depression and may induce a switch to mania and/or rapid cycling over the long term. Moreover, some pharmacological agents that are effective in treating bipolar depression, such as quetiapine and olanzapinefluoxetine, may be associated with important cardiometabolic side effects (especially weight gain) over the long term, which compromise patients' physical health, increasing the risk of morbidity and mortality, and/or the likelihood of treatment non-adherence and associated relapse. More recently, evidence for certain atypical antipsychotics, such as lurasidone and cariprazine, has demonstrated that it may be possible to effectively manage bipolar depression without unduly compromising patients' long-term physical health. Furthermore, although most of the current treatment options for bipolar depression generally target central dopaminergic and serotonergic systems, emerging evidence for several novel therapeutic targets, including the glutamatergic system and inflammatory processes, indicates the potential for alternative pharmacological treatment approaches for bipolar depression in the future. Bipolar depression causes substantial mortality, morbidity and impairment of quality of life, and its effective management currently represents an important unmet need. It is hoped that new and emerging pharmacological treatments for this challenging condition will help address this need.

\section{Acknowledgments}

Editorial support for the preparation of this manuscript was provided by John Scopes of $\mathrm{m} X \mathrm{~m}$ Medical Communications.

\section{Funding}

This report represents independent research funded by the National Institute for Health Research (NIHR) Biomedical Research Centre at South London and Maudsley NHS Foundation Trust and King's College London. The views expressed are those of the authors and not necessarily those of the NHS, the NIHR, or the Department of Health. Editorial support for the preparation of this publication was funded by Sunovion Pharmaceuticals.

\section{Disclosure}

Nefize Yalin is employed by the Centre for Affective Disorders, Institute of Psychiatry, Psychology and Neuroscience, King's College London, UK. She has worked as a researcher in clinical studies conducted together with Jannsen Cliag, Corcept Therapeutics and COMPASS Pathways. She also reports non-financial support from $\mathrm{mXm}$ Medical Communications and grants from Sunovion
Pharmaceuticals, during the conduct of the study. Allan Young is employed by the Centre for Affective Disorders, Institute of Psychiatry, Psychology and Neuroscience, King's College London, UK, and is an Honorary Consultant at the Maudsley Hospital, London, UK (UK NHS). He has conducted paid lectures and advisory boards for Allergan, AstraZeneca, Bionomics, BrainCells Inc., Bristol-Myers Squibb, Eli Lilly, GlaxoSmithKline, Janssen, Lundbeck, Novartis, Otsuka Pharmaceutical Co., Pharmaceutica, Pfizer, Roche, Sanofi-Aventis, Servier Laboratories, Sunovion and Wyeth. He has no shareholdings in pharmaceutical companies. He was lead Investigator for the EMBOLDEN Study (AstraZeneca), BCI Neuroplasticity Study and Aripiprazole Mania Study, and has been involved in investigator-initiated studies for AstraZeneca, Eli Lilly and Wyeth. He was also the Principal Investigator in the Restore-Life VNS registry study funded by LivaNova. Principal Investigator on ESKETINTRD3004: “An Open-label, Long-term, Safety and Efficacy Study of Intranasal Esketamine in Treatment-resistant Depression" For Janssen/Johnson \& Johnson; Principal Investigator on "The Effects of Psilocybin on Cognitive Function in Healthy Participants" for Compass; Principal Investigator on "The Safety and Efficacy of Psilocybin in Participants with Treatment-Resistant Depression (P-TRD)" for Livanova. He has received grant funding (past and present) from: NIMH (USA); NIHR (UK); CIHR (Canada); NARSAD (USA); Stanley Medical Research Institute (USA); MRC (UK); Wellcome Trust (UK); Royal College of Physicians (Edin); BMA (UK); VGH \& UBC Foundation (Canada); WEDC (Canada); CCS Depression Research Fund (Canada); and MSFHR (Canada). The authors report no other conflicts of interest in this work.

\section{References}

1. Judd LL, Akiskal HS, Schettler PJ, et al. The long-term natural history of the weekly symptomatic status of bipolar I disorder. Arch Gen Psychiatry. 2002;59(6):530-537. doi:10.1001/archpsyc.59.6.530

2. Judd LL, Akiskal HS, Schettler PJ, et al. A prospective investigation of the natural history of the long-term weekly symptomatic status of bipolar II disorder. Arch Gen Psychiatry. 2003;60(3):261-269. doi:10.1001/ archpsyc.60.3.261

3. Bauer MS, Kirk GF, Gavin C, Williford WO. Determinants of functional outcome and healthcare costs in bipolar disorder: a high-intensity follow-up study. J Affect Disord. 2001;65(3):231-241. doi:10.1016/S0165-0327(00) 00247-0

4. Calabrese JR, Hirschfeld RM, Frye MA, Reed ML. Impact of depressive symptoms compared with manic symptoms in bipolar disorder: results of a U.S. community-based sample. J Clin Psychiatry. 2004;65 (11):1499-1504. doi:10.4088/JCP.v65n1109

5. Michalak EE, Murray G, Young AH, Lam RW. Burden of bipolar depression: impact of disorder and medications on quality of life. CNS Drugs. 2008;22(5):389-406. doi:10.2165/00023210-200822050-00003 
6. Schaffer A, Isometsa ET, Tondo L, et al. Epidemiology, neurobiology and pharmacological interventions related to suicide deaths and suicide attempts in bipolar disorder: part I of a report of the International Society for Bipolar Disorders Task Force on Suicide in bipolar disorder. Aust N Z J Psychiatry. 2015;49(9):785-802. doi:10.1177/0004867415594427

7. Dome P, Rihmer Z, Gonda X. Suicide risk in bipolar disorder: a brief review. Medicina (Kaunas). 2019;55(8):403.

8. Pompili M, Shrivastava A, Serafini G, et al. Bereavement after the suicide of a significant other. Indian J Psychiatry. 2013;55(3):256263. doi:10.4103/0019-5545.117145

9. Mathews DC, Richards EM, Niciu MJ, Ionescu DF, Rasimas JJ, Zarate CA Jr. Neurobiological aspects of suicide and suicide attempts in bipolar disorder. Transl Neurosci. 2013;4(2). doi:10.2478/s13380-013-0120-7

10. Pompili M, Gibiino S, Innamorati M, et al. Prolactin and thyroid hormone levels are associated with suicide attempts in psychiatric patients. Psychiatry Res. 2012;200(2-3):389-394. doi:10.1016/j. psychres.2012.05.010

11. Mitchell PB, Goodwin GM, Johnson GF, Hirschfeld RM. Diagnostic guidelines for bipolar depression: a probabilistic approach. Bipolar Disord. 2008;10(1 Pt 2):144-152. doi:10.1111/ j.1399-5618.2007.00559.x

12. Leverich GS, Altshuler LL, Frye MA, et al. Risk of switch in mood polarity to hypomania or mania in patients with bipolar depression during acute and continuation trials of venlafaxine, sertraline, and bupropion as adjuncts to mood stabilizers. Am $J$ Psychiatry. 2006;163(2):232-239. doi:10.1176/appi.ajp.163.2.232

13. Crump C, Sundquist K, Winkleby MA, Sundquist J. Comorbidities and mortality in bipolar disorder: a Swedish national cohort study. JAMA Psychiatry. 2013;70(9):931-939. doi:10.1001/jamapsychiatry.2013. 1394

14. Chang CK, Hayes RD, Perera G, et al. Life expectancy at birth for people with serious mental illness and other major disorders from a secondary mental health care case register in London. PLoS One. 2011;6(5):e19590. doi:10.1371/journal.pone.0019590

15. Mao R, Zhang C, Chen J, et al. Different levels of pro- and antiinflammatory cytokines in patients with unipolar and bipolar depression. J Affect Disord. 2018;237:65-72. doi:10.1016/j.jad.2018.04.115

16. Yatham LN, Kennedy SH, Parikh SV, et al. Canadian Network for Mood and Anxiety Treatments (CANMAT) and International Society for Bipolar Disorders (ISBD) 2018 guidelines for the management of patients with bipolar disorder. Bipolar Disord. 2018;20(2):97-170.

17. Goodwin GM, Haddad PM, Ferrier IN, et al. Evidence-based guidelines for treating bipolar disorder: revised third edition recommendations from the British Association for Psychopharmacology. $J$ Psychopharmacol. 2016;30(6):495-553. doi:10.1177/02698811166 36545

18. National Institute for Health and Care Excellence. Clinical Guideline Number 185 (CG185); Bipolar disorder: assessment and management. Available from: https://www.nice.org.uk/gui dance/cg185/resources/bipolar-disorder-assessment-and-manage ment-pdf-35109814379461. Accessed December 17, 2019.

19. Grunze H, Vieta E, Goodwin GM, et al. The World Federation of Societies of Biological Psychiatry (WFSBP) guidelines for the biological treatment of bipolar disorders: update 2010 on the treatment of acute bipolar depression. World J Biol Psychiatry. 2010;11 (2):81-109. doi:10.3109/15622970903555881

20. Pfennig A, Bschor T, Baghai T, et al. [S3 guidelines on diagnostics and therapy of bipolar disorders: development process and essential recommendations]. Nervenarzt. 2012;83(5):568-586. German. doi:10.1007/s00115-011-3415-3

21. Hasler G, Preisig M, Müller T, et al. Bipolare Störungen: update 2015. Schweizerisches Med Forum. 2015;15(20-21):486-494.
22. Malhi GS, Bassett D, Boyce P, et al. Royal Australian and New Zealand College of Psychiatrists clinical practice guidelines for mood disorders. Aust N Z J Psychiatry. 2015;49(12):1087-1206. doi:10.1177/0004867415617657

23. Young AH, McElroy SL, Bauer M, et al. A double-blind, placebocontrolled study of quetiapine and lithium monotherapy in adults in the acute phase of bipolar depression (EMBOLDEN I). $J$ Clin Psychiatry. 2010;71(2):150-162. doi:10.4088/JCP.08m04995gre

24. Kim SJ, Lee YJ, Lee YJ, Cho SJ. Effect of quetiapine XR on depressive symptoms and sleep quality compared with lithium in patients with bipolar depression. J Affect Disord. 2014;157:33-40. doi:10.1016/j.jad.2013.12.032

25. Burgess S, Geddes J, Hawton K, Townsend E, Jamison K, Goodwin G. Lithium for maintenance treatment of mood disorders. Cochrane Database Syst Rev. 2001;3:CD003013.

26. Vieta E, Gunther O, Locklear J, et al. Effectiveness of psychotropic medications in the maintenance phase of bipolar disorder: a metaanalysis of randomized controlled trials. Int J Neuropsychopharmacol. 2011;14(8):1029-1049. doi:10.1017/S1461145711000885

27. Smith KA, Cipriani A. Lithium and suicide in mood disorders: updated meta-review of the scientific literature. Bipolar Disord. 2017;19(7):575-586. doi:10.1111/bdi.12543

28. Bond DJ, Lam RW, Yatham LN. Divalproex sodium versus placebo in the treatment of acute bipolar depression: a systematic review and meta-analysis. $J$ Affect Disord. 2010;124(3):228-234. doi:10.1016/j.jad.2009.11.008

29. Wieck A, Jones S. Dangers of valproate in pregnancy. BMJ. 2018;361:k1609. doi:10.1136/bmj.k1609

30. Gijsman HJ, Geddes JR, Rendell JM, Nolen WA, Goodwin GM. Antidepressants for bipolar depression: a systematic review of randomized, controlled trials. Am J Psychiatry. 2004;161 (9):1537-1547. doi:10.1176/appi.ajp.161.9.1537

31. Sachs GS, Nierenberg AA, Calabrese JR, et al. Effectiveness of adjunctive antidepressant treatment for bipolar depression. $N$ Engl $J$ Med. 2007;356(17):1711-1722. doi:10.1056/NEJMoa064135

32. Sidor MM, Macqueen GM. Antidepressants for the acute treatment of bipolar depression: a systematic review and meta-analysis. J Clin Psychiatry. 2011;72(2):156-167. doi:10.4088/ JCP.09r05385gre

33. Fornaro M, Anastasia A, Novello S, et al. Incidence, prevalence and clinical correlates of antidepressant-emergent mania in bipolar depression: a systematic review and meta-analysis. Bipolar Disord. 2018;20(3):195-227. doi:10.1111/bdi.12612

34. Pacchiarotti I, Bond DJ, Baldessarini RJ, et al. The International Society for Bipolar Disorders (ISBD) task force report on antidepressant use in bipolar disorders. Am J Psychiatry. 2013;170 (11):1249-1262. doi:10.1176/appi.ajp.2013.13020185

35. Beyer JL. The use of antidepressants in bipolar depression. Handb Exp Pharmacol. 2019;250:415-442.

36. American Psychiatry Association. Practice guideline for the treatment of patients with bipolar disorder. Available from: http://psy chiatryonline.org/pb/assets/raw/sitewide/practice_guidelines/guide lines/bipolar.pdf. Accessed 17 December 2019.

37. Eli Lilly and Company. SYMBYAX ${ }^{\circledR}$ Prescribing Information. Available from: https://www.accessdata.fda.gov/drugsatfda_docs/ label/2009/021520s022lbl.pdf. Accessed 17 December 2019.

38. Calabrese JR, Huffman RF, White RL, et al. Lamotrigine in the acute treatment of bipolar depression: results of five double-blind, placebo-controlled clinical trials. Bipolar Disord. 2008;10(2):323333. doi:10.1111/j.1399-5618.2007.00500.x

39. Calabrese JR, Bowden CL, Sachs GS, Ascher JA, Monaghan E, Rudd GD. A double-blind placebo-controlled study of lamotrigine monotherapy in outpatients with bipolar I depression. Lamictal 602 Study Group. J Clin Psychiatry. 1999;60(2):79-88. doi:10.4088/JCP.v60n0203 
40. van der Loos ML, Mulder PG, Hartong EG, et al. Efficacy and safety of lamotrigine as add-on treatment to lithium in bipolar depression: a multicenter, double-blind, placebo-controlled trial. $J$ Clin Psychiatry. 2009;70(2):223-231. doi:10.4088/JCP.08m04152

41. McElroy SL, Zarate CA, Cookson J, et al. A 52-week, open-label continuation study of lamotrigine in the treatment of bipolar depression. J Clin Psychiatry. 2004;65(2):204-210. doi:10.4088/ JCP.v65n0210

42. GlaxoSmithKline. Lamictal ${ }^{\circledR}$ summary of product characteristics. Available from: https://www.ema.europa.eu/documents/referral/ lamictal-article-30-referral-annex-i-ii-iii_en.pdf.

43. Zarate CA Jr, Tohen M. Double-blind comparison of the continued use of antipsychotic treatment versus its discontinuation in remitted manic patients. Am J Psychiatry. 2004;161(1):169-171. doi:10.1176/appi ajp.161.1.169

44. AstraZeneca. Seroquel ${ }^{\circledR}$ summary of product characteristics. Available from: https://www.ema.europa.eu/en/documents/referral/ seroquel-seroquel-xr-associated-names-article-30-referral-annexiii_en.pdf. Accessed 17 December 2019.

45. Sunovion Pharmaceuticals Inc. Latuda ${ }^{\circledR}$ Prescribing Information. Available from: https://www.latuda.com/LatudaPrescribingInf ormation.pdf. Accessed 17 December 2019.

46. Ray WA, Chung CP, Murray KT, Hall K, Stein CM. Atypical antipsychotic drugs and the risk of sudden cardiac death. $N$ Engl $J$ Med. 2009;360(3):225-235. doi:10.1056/NEJMoa0806994

47. Cha DS, McIntyre RS. Treatment-emergent adverse events associated with atypical antipsychotics. Expert Opin Pharmacother. 2012;13(11):1587-1598. doi:10.1517/14656566.2012.656590

48. Suttajit S, Srisurapanont M, Maneeton N, Maneeton B. Quetiapine for acute bipolar depression: a systematic review and meta-analysis. Drug Des Devel Ther. 2014;8:827-838. doi:10.2147/DDDT. S63779

49. Tohen M, Vieta E, Calabrese J, et al. Efficacy of olanzapine and olanzapine-fluoxetine combination in the treatment of bipolar I depression. Arch Gen Psychiatry. 2003;60(11):1079-1088. doi:10.1001/ archpsyc.60.11.1079

50. Ketter TA, Miller S, Dell'Osso B, Calabrese JR, Frye MA, Citrome L. Balancing benefits and harms of treatments for acute bipolar depression. J Affect Disord. 2014;169(Suppl 1):S24-S33. doi:10. 1016/S0165-0327(14)70006-0

51. Loebel A, Cucchiaro J, Silva R, et al. Lurasidone as adjunctive therapy with lithium or valproate for the treatment of bipolar I depression: a randomized, double-blind, placebo-controlled study. Am J Psychiatry. 2014;171(2):169-177. doi:10.1176/appi.ajp.2013.13070985

52. Loebel A, Cucchiaro J, Silva R, et al. Lurasidone monotherapy in the treatment of bipolar I depression: a randomized, double-blind, placebo-controlled study. Am J Psychiatry. 2014;171(2):160-168. doi:10.1176/appi.ajp.2013.13070984

53. Suppes T, Kroger H, Pikalov A, Loebel A. Lurasidone adjunctive with lithium or valproate for bipolar depression: a placebo-controlled trial utilizing prospective and retrospective enrolment cohorts. $J$ Psychiatr Res. 2016;78:86-93. doi:10.1016/j.jpsychires.2016.03.012

54. Citrome L, Ketter TA, Cucchiaro J, Loebel A. Clinical assessment of lurasidone benefit and risk in the treatment of bipolar I depression using number needed to treat, number needed to harm, and likelihood to be helped or harmed. J Affect Disord. 2014;155:20-27. doi:10.1016/j. jad.2013.10.040

55. Thase ME, Jonas A, Khan A, et al. Aripiprazole monotherapy in nonpsychotic bipolar I depression: results of 2 randomized, placebo-controlled studies. J Clin Psychopharmacol. 2008;28(1):1320. doi:10.1097/jcp.0b013e3181618eb4

56. Thase ME, Bowden CL, Nashat M, et al. Aripiprazole in bipolar depression: a pooled, post-hoc analysis by severity of core depressive symptoms. Int $J$ Psychiatry Clin Pract. 2012;16(2):121-131. doi:10.3109/13651501.2011.632680
57. Keck PE Jr, Calabrese JR, McIntyre RS, et al. Aripiprazole monotherapy for maintenance therapy in bipolar I disorder: a 100-week, double-blind study versus placebo. J Clin Psychiatry. 2007;68 (10):1480-1491. doi:10.4088/JCP.v68n1003

58. Marcus R, Khan A, Rollin L, et al. Efficacy of aripiprazole adjunctive to lithium or valproate in the long-term treatment of patients with bipolar I disorder with an inadequate response to lithium or valproate monotherapy: a multicenter, double-blind, randomized study. Bipolar Disord. 2011;13(2):133-144. doi:10.1111/j.13995618.2011.00898.x

59. Stahl SM. Mechanism of action of cariprazine. CNS Spectr. 2016;21(2):123-127. doi:10.1017/S1092852916000043

60. Durgam S, Earley W, Lipschitz A, et al. An 8-week randomized, double-blind, placebo-controlled evaluation of the safety and efficacy of cariprazine in patients with bipolar i depression. Am J Psychiatry. 2016;173(3):271-281. doi:10.1176/appi.ajp.2015.15020164

61. Earley W, Burgess MV, Rekeda L, et al. Cariprazine treatment of bipolar depression: a randomized double-blind placebo-controlled phase 3 study. Am J Psychiatry. 2019;176(6):439-448. doi:10.1176/ appi.ajp.2018.18070824

62. Grady SE, Marsh TA, Tenhouse A, Klein K. Ketamine for the treatment of major depressive disorder and bipolar depression: A review of the literature. Ment Health Clin. 2017;7(1):16-23. doi:10.9740/mhc.2017.01.016

63. Zarate C Jr, Machado-Vieira R, Henter I, Ibrahim L, Diazgranados N, Salvadore G. Glutamatergic modulators: the future of treating mood disorders? Harv Rev Psychiatry. 2010;18(5):293-303. doi:10.3109/10673229.2010.511059

64. Leboyer M, Soreca I, Scott J, et al. Can bipolar disorder be viewed as a multi-system inflammatory disease? J Affect Disord. 2012;141 (1):1-10. doi:10.1016/j.jad.2011.12.049

65. Rosenblat JD, Kakar R, Berk M, et al. Anti-inflammatory agents in the treatment of bipolar depression: a systematic review and meta-analysis. Bipolar Disord. 2016;18(2):89-101. doi:10.1111/bdi.12373

66. Murrough JW, Huryk KM, Mao X, et al. A pilot study of minocycline for the treatment of bipolar depression: effects on cortical glutathione and oxidative stress in vivo. $J$ Affect Disord. 2018;230:56-64. doi:10.1016/j.jad.2017.12.067

67. Parmentier T, Sienaert P. The use of triiodothyronine (T3) in the treatment of bipolar depression: a review of the literature. $J$ Affect Disord. 2018;229:410-414. doi:10.1016/j.jad.2017.12.071

68. Frye MA, Amchin J, Bauer M, Adler C, Yang R, Ketter TA. Randomized, placebo-controlled, adjunctive study of armodafinil for bipolar I depression: implications of novel drug design and heterogeneity of concurrent bipolar maintenance treatments. Int $J$ Bipolar Disord. 2015;3(1):34. doi:10.1186/s40345-015-0034-0

69. Frye MA, Grunze H, Suppes T, et al. A placebo-controlled evaluation of adjunctive modafinil in the treatment of bipolar depression. Am J Psychiatry. 2007;164(8):1242-1249. doi:10.1176/appi.ajp.2007.06060 981

70. Goldberg JF, Burdick KE, Endick CJ. Preliminary randomized, double-blind, placebo-controlled trial of pramipexole added to mood stabilizers for treatment-resistant bipolar depression. $\mathrm{Am} \mathrm{J}$ Psychiatry. 2004;161(3):564-566. doi:10.1176/appi.ajp.161.3.564

71. Brown ES, Khaleghi N, Van Enkevort E, et al. A pilot study of brexpiprazole for bipolar depression. $J$ Affect Disord. 2019;249:315-318. doi:10.1016/j.jad.2019.02.056

72. Krystal JH, Karper LP, Seibyl JP, et al. Subanesthetic effects of the noncompetitive NMDA antagonist, ketamine, in humans. Psychotomimetic, perceptual, cognitive, and neuroendocrine responses. Arch Gen Psychiatry. 1994;51(3):199-214. doi:10.10 01/archpsyc.1994.03950030035004

73. Parsaik AK, Singh B, Khosh-Chashm D, Mascarenhas SS. Efficacy of ketamine in bipolar depression: systematic review and metaanalysis. J Psychiatr Pract. 2015;21(6):427-435. doi:10.1097/ PRA.0000000000000106 
74. Romeo B, Choucha W, Fossati P, Rotge JY. Meta-analysis of short- and mid-term efficacy of ketamine in unipolar and bipolar depression. Psychiatry Res. 2015;230(2):682-688. doi:10.1016/j.psychres.2015.10. 032

75. McCloud TL, Caddy C, Jochim J, et al.. Ketamine and other glutamate receptor modulators for depression in bipolar disorder in adults. Cochrane Database Syst Rev. 2015;9:CD011611.

76. Kishimoto T, Chawla JM, Hagi K, et al. Single-dose infusion ketamine and non-ketamine N-methyl-d-aspartate receptor antagonists for unipolar and bipolar depression: a meta-analysis of efficacy, safety and time trajectories. Psychol Med. 2016;46(7):14591472. doi:10.1017/S0033291716000064

77. Bobo WV, Vande Voort JL, Croarkin PE, Leung JG, Tye SJ, Frye MA. Ketamine for treatment-resistant unipolar and bipolar major depression: critical review and implications for clinical practice. Depress Anxiety. 2016;33(8):698-710. doi:10.1002/da.22505

78. Thomas RK, Baker G, Lind J, Dursun S. Rapid effectiveness of intravenous ketamine for ultraresistant depression in a clinical setting and evidence for baseline anhedonia and bipolarity as clinical predictors of effectiveness. J Psychopharmacol. 2018;32(10):11101117. doi:10.1177/0269881118793104

79. Saligan LN, Luckenbaugh DA, Slonena EE, Machado-Vieira R, Zarate CA Jr. An assessment of the anti-fatigue effects of ketamine from a double-blind, placebo-controlled, crossover study in bipolar disorder. $J$ Affect Disord. 2016;194:115-119. doi:10.1016/j.jad.2016.01.009

80. Kraus C, Rabl U, Vanicek T, et al. Administration of ketamine for unipolar and bipolar depression. Int $J$ Psychiatry Clin Pract. 2017;21(1):2-12. doi:10.1080/13651501.2016.1254802

81. Aan Het Rot M, Zarate CA Jr, Charney DS, Mathew SJ. Ketamine for depression: where do we go from here? Biol Psychiatry. 2012;72(7):537-547. doi:10.1016/j.biopsych.2012.05.003

82. Calabrese JR, Ketter TA, Youakim JM, Tiller JM, Yang R, Frye MA. Adjunctive armodafinil for major depressive episodes associated with bipolar I disorder: a randomized, multicenter, double-blind, placebo-controlled, proof-of-concept study. J Clin Psychiatry. 2010;71(10):1363-1370. doi:10.4088/JCP.09m05900gry

83. Calabrese JR, Frye MA, Yang R, Ketter TA. Armodafinil treatment trial study $n$. efficacy and safety of adjunctive armodafinil in adults with major depressive episodes associated with bipolar I disorder: a randomized, double-blind, placebo-controlled, multicenter trial. J Clin Psychiatry. 2014;75(10):1054-1061. doi:10.4088/JCP.13m08951

84. Ketter TA, Amchin J, Frye MA, Gross N. Long-term safety and efficacy of armodafinil in bipolar depression: A 6-month open-label extension study. J Affect Disord. 2016;197:51-57. doi:10.1016/j.jad.2016.02.050

85. Zarate CA Jr, Payne JL, Singh J, et al. Pramipexole for bipolar II depression: a placebo-controlled proof of concept study. Biol Psychiatry. 2004;56(1):54-60. doi:10.1016/j.biopsych.2004.03.013

86. Sporn J, Ghaemi SN, Sambur MR, et al. Pramipexole augmentation in the treatment of unipolar and bipolar depression: a retrospective chart review. Ann Clin Psychiatry. 2000;12(3):137-140. doi:10.3109/10401230009147102

87. Lattanzi L, Dell'Osso L, Cassano P, et al. Pramipexole in treatmentresistant depression: a 16-week naturalistic study. Bipolar Disord. 2002;4(5):307-314. doi:10.1034/j.1399-5618.2002.01171.x
88. Urbani A, Belluzzi O. Riluzole inhibits the persistent sodium current in mammalian CNS neurons. Eur J Neurosci. 2000;12 (10):3567-3574. doi:10.1046/j.1460-9568.2000.00242.x

89. Zarate CA Jr, Quiroz JA, Singh JB, et al. An open-label trial of the glutamate-modulating agent riluzole in combination with lithium for the treatment of bipolar depression. Biol Psychiatry. 2005;57 (4):430-432. doi:10.1016/j.biopsych.2004.11.023

90. Park LT, Lener MS, Hopkins M, et al. A Double-blind, placebocontrolled, pilot study of riluzole monotherapy for acute bipolar depression. J Clin Psychopharmacol. 2017;37(3):355-358. doi:10.1097/JCP.0000000000000693

91. Dean O, Giorlando F, Berk M. N-acetylcysteine in psychiatry: current therapeutic evidence and potential mechanisms of action. J Psychiatry Neurosci. 2011;36(2):78-86. doi:10.1503/jpn.100057

92. Berk M, Copolov DL, Dean O, et al. N-acetyl cysteine for depressive symptoms in bipolar disorder-a double-blind randomized placebo-controlled trial. Biol Psychiatry. 2008;64(6):468-475. doi:10.1016/j.biopsych.2008.04.022

93. Berk M, Dean OM, Cotton SM, et al. Maintenance N-acetyl cysteine treatment for bipolar disorder: a double-blind randomized placebo controlled trial. BMC Med. 2012;10(1):91. doi:10.1186/1741-7015-10-91

94. Ellegaard PK, Licht RW, Poulsen HE, et al. Add-on treatment with $\mathrm{N}$-acetylcysteine for bipolar depression: a 24-week randomized double-blind parallel group placebo-controlled multicentre trial (NACOS-study protocol). Int J Bipolar Disord. 2018;6(1):11. doi:10.1186/s40345-018-0117-9

95. Soczynska JK, Kennedy SH, Alsuwaidan M, et al. A pilot, openlabel, 8-week study evaluating the efficacy, safety and tolerability of adjunctive minocycline for the treatment of bipolar I/II depression. Bipolar Disord. 2017;19(3):198-213. doi:10.1111/bdi.12496

96. Savitz JB, Teague TK, Misaki M, et al. Treatment of bipolar depression with minocycline and/or aspirin: an adaptive, $2 \times 2$ double-blind, randomized, placebo-controlled, phase IIA clinical trial. Transl Psychiatry. 2018;8(1):27. doi:10.1038/s41398-017-0073-7

97. Edberg D, Hoppensteadt D, Walborn A, Fareed J, Sinacore J, Halaris A. Plasma C-reactive protein levels in bipolar depression during cyclooxygenase-2 inhibitor combination treatment. $J$ Psychiatr Res. 2018;102:1-7. doi:10.1016/j.jpsychires.2018.02.004

98. Husain MI, Chaudhry IB, Hamirani MM, et al. Minocycline and celecoxib as adjunctive treatments for bipolar depression: a study protocol for a multicenter factorial design randomized controlled trial. Neuropsychiatr Dis Treat. 2017;13:1-8. doi:10.2147/NDT.S115002

99. Kelly T, Lieberman DZ. The use of triiodothyronine as an augmentation agent in treatment-resistant bipolar II and bipolar disorder NOS. $J$ Affect Disord. 2009;116(3):222-226. doi:10.1016/j. jad.2008.12.010

100. Banki CM. Cerebrospinal fluid amine metabolites after combined amitriptyline-triiodothyronine treatment of depressed women. Eur $J$ Clin Pharmacol. 1977;11(4):311-315. doi:10.1007/BF00607682

101. Nakamura M, Nagamine T. Brexpiprazole as a new serotonindopamine receptor modulator: considering the clinical relevance for metabolic parameters and prolactin levels. Innov Clin Neurosci. 2019;16(9-10):30-32.
Neuropsychiatric Disease and Treatment

\section{Publish your work in this journal}

Neuropsychiatric Disease and Treatment is an international, peerreviewed journal of clinical therapeutics and pharmacology focusing on concise rapid reporting of clinical or pre-clinical studies on a range of neuropsychiatric and neurological disorders. This journal is indexed on PubMed Central, the 'PsycINFO' database and CAS, and is the official journal of The International Neuropsychiatric Association (INA). The manuscript management system is completely online and includes a very quick and fair peer-review system, which is all easy to use. Visit http://www.dovepress.com/testimonials.php to read real quotes from published authors. 